British Scholar

Vol. III, Issue 2, 191-218, September 2010

\title{
Global Influences and Local Environments: Forestry and Forest Conservation in New Zealand, 1850s-1925 ${ }^{1}$
}

\author{
James Beattie and Paul Star
}

'in the matter of forests, the Anglo-Saxon is the last man in the world that ought to be left alone.'

\footnotetext{
James Beattie, Senior Lecturer, History Programme, University of Waikato, Private Bag 3105, Hamilton 3240, Waikato, New Zealand, jbeattie@waikato.ac.nz. He publishes on Asian and Australasian imperial environmental history, Chinese art collecting, garden history and the history of science. Current projects include: Chinoiserie in Australasia (with Duncan Campbell); Australasian garden history (with Katie Holmes); Dunedin Chinese Garden (with Campbell) and Empire and Environmental Anxiety, 1800-1920 to be published by Palgrave in 2010. Paul Star, formerly Department of History, University of Otago, Dunedin, New Zealand, starmulq@ihug.co.nz. He has published widely on New Zealand environmental history, contributing a chapter to the New Oxford History of New Zealand (2009) and co-authoring three chapters in the forthcoming Seeds of Empire, to be published by I.B. Tauris in 2010. Current projects include: private and public afforestation in New Zealand; the role of nurserymen and others in global plant and animal transfers.
}

1 The authors wish to thank: The Faculty of Arts and Social Sciences (FASS) Contestable Research Grant, University of Waikato, for employing Joanna Clarke to update footnotes; FASS for a 'Small Research Grant' to enable Dr. Star to visit the University of Waikato in 2008 for he and Dr. Beattie to work on updating the project; and Wendy Harrex, Editor, University of Otago Press, for encouraging the authors to update an earlier chapter. Thanks also to Mrs Hall and Michael Bruner for information about Colonel de Renzie Brett, Michael Clark, Rosemary Thompson, Noel Frizzel and the Browns of Kirwee, as well as Dr. Douglas Simes, for looking up material in the British Library for the authors. We also thank the two anonymous referees for their comments. A different version of this paper first appeared as: James Beattie, and Paul Star, 'State Forest Conservation and the New Zealand Landscape: Origins and Influences, 1850-1914', in Landscape/Community: Perspectives from New Zealand History, eds. Tony Ballantyne and Judith A. Bennett (Dunedin, 2005), pp. 17-29, and another version will be published in Vinita Damodaran et.al edited, The British Empire and the Natural World (Oxford, forthcoming).

2 New Zealand Parliamentary Debates (henceforth NZPD), 31 July (1874), p. 360. 
Sir John Cracroft Wilson was in a good position to judge British forest use in one of its colonies. Having migrated to New Zealand in the 1850s after decades of working in the East India Company civil service, he bore witness to the destruction of countless acres of forest in his new home. Even his beloved seven acres of preserved forest on the Port Hills, above Lyttelton (Christchurch), had recently been consumed with fire, the destruction leading to the loss of an area which had, he described, 'gladdened my sight for six years' since its purchase. ${ }^{3}$ Wilson's personal testimony to the loss of forestland was made during one of several parliamentary debates in New Zealand in the 1870s that were centred around the need to preserve forests and, in Wilson's conceptualisation, to ensure that the British would not destroy them.

This article examines the multiple factors that shaped the establishment of forest conservation and tree-planting in the colony of New Zealand. It presents a new perspective on forest history in New Zealand from the 1850s to the 1920s by examining the interplay of local and global factors in the development of forestry, while also suggesting future research topics in this area. Using the case-study of New Zealand, as an ancillary focus the article presents new interpretations of the exchange and introduction of forestry ideas, suggesting a need to reexamine the importance of locality in the period leading up to the emergence of 'empire forestry' in the twentieth century. With this in mind, it takes as one of its perspectives the work of historian of science David Livingstone, who has emphasised the importance of local factors in shaping the spread of scientific ideas. ${ }^{4}$ In light of Livingstone's ideas, we demonstrate that while it makes sense to consider New Zealand forest policy both nationally and internationally, there were also significant local variations in policy according to geography, politics and other factors. These included uneven forest distribution throughout the country, slower growth-rates of indigenous trees and the impact of geography on forest removal and conservation. As well, long-standing political aversion to government interference in society restricted the role of the state in active forest management, giving greater latitude to private tree-planters. Meanwhile, New Zealand's smaller government and population offered greater power to individuals than perhaps would be open to those living in larger societies with bigger government bureaucracies.

3 Ibid., p. 362.

4 David Livingstone, Putting Science in Its Place: Geographies of Scientific Knowledge (Chicago and London, 2003). 


\section{Early forest history}

New Zealand's remarkable natural history is tremendously important to understanding its later forest history. As a landmass spatially isolated for the last eighty million years and biologically so for all that time except the last few centuries, the first three terrestrial mammals - Polynesian humans, dogs and rats (Rattus exulans) - only arrived there around $1200 \mathrm{CE}$. They remained the only significant terrestrial mammals on the islands until contact with Europeans from the late eighteenth century in a short time released a veritable biological floodgate. ${ }^{5}$ Before human arrival, forest loomed over much of the New Zealand landscape. Conifer and broadleaf forest predominated, while kauri (of the araucaria family) dominated in the far north. Elsewhere in the North Island, and in the east and mid-west of the South Island, the largest species were podocarps - softwoods that the Polynesians and their Māori descendants called kahikatea (Dacrycarpus dacrydioides), matai (Prumnopitys taxifolia) and rimu (Dacrydium cupressinum), and that later European settlers, noting the colour of their timber, called white pine, black pine and red pine respectively. A quite different hardwood clothed the South Island. ${ }^{6}$ Called tawhai by Māori and birch by European settlers, it is now known more correctly as native beech or Nothofagus. All of these trees are endemic species that evolved without competition from browsing mammals. Most are slow growing. Kauri may live over a thousand years and attain a height of fifty metres; kahikatea, in the space of about eight hundred years, grow even taller.

Fire, which few native tree species can withstand, altered the face of the New Zealand landscape. With an increase in the extent and frequency of fires after the arrival of humans, fern and tussock came to replace forest over much of eastern New Zealand. Scholars still debate the relative influence of humans and climate change in that process ${ }^{7}$ but, whatever the cause, forest assumed a significant role in Māori society. Everything from weapons to waka (canoes), to the harbouring of birdlife which proliferated therein and remained an important food source, depended on forestland. ${ }^{8}$ Many Pacific concepts - like mana (energy and being),

5 Trevor Worthy and Richard Holdaway, The Lost World of the Moa: Prebistoric Life of New Zealand (Christchurch, 2002).

6 Softwoods are conifers (gymnosperms), while hardwoods are flowering trees (angiosperms). Confusingly, softwoods do not necessarily have the softer wood, though this tends to be the case.

7 Atholl Anderson, 'A Fragile Plenty: Pre-European Maori and the New Zealand Environment', in Environmental Histories of New Zealand, eds. Tom Brooking and Eric Pawson (Melbourne, 2002), pp. 19-34.

8 On which, see Matt McGlone, 'The Polynesian Settlement of New Zealand in Relation 
tapu (religious restriction) and mauri (a life force infusing the world) - could be applied readily enough to Aotearoa (the Māori word for New Zealand) and led to practices like resource rahui (restriction) that were applied to forests as well as other resources. On the other hand, many of the horticultural practices they brought with them were not so easily applicable. In New Zealand's cooler temperate landmass, tropical food plants faced barriers to growth. As a consequence, Māori relied heavily on the natural resources of New Zealand, engaging in a process Tim Flannery has memorably termed 'resource eating': the rapid consumption of resources leading to a slump requiring the discovery of new food sources. ${ }^{9}$

A resource crunch put the brakes on the accelerating Māori population sometime in the seventeenth century or earlier. After several hundred years of occupation, large avifauna and other species had disappeared along with their habitat - the forest, principally on the east coast. While Māori turned their attention to marine resources, reduced growth rates sometimes led to the total failure of their tropical crops. Cultivation required Māori to fire regularly to clear both bracken fern and manuka at the required time of the year, for horticultural and probably also for strategic reasons. Firing regularly to provide ash and using seaweed as manure to avoid soil exhaustion, Maori also shifted from one plot to another, and especially in southern South Island relied on a different array of resources (from mutton birds to eels) than those utilised in more northerly parts, where horticulture predominated. The sum effects of these changes meant, even if they did not know it, that when Europeans arrived, they encountered a significantly altered landscape. ${ }^{10}$

Formal colonization in 1840 saw the British Crown and many Māori chiefs signing the Treaty of Waitangi. By this time, an estimated 100,000 Māori lived in Aotearoa/New Zealand, most in the warmer North Island. In this period, many Māori tribes succeeded as traders, exporting newly introduced food crops as far away as Australia. But from the 1860 s, the balance of power tipped towards the ever-increasing numbers of settlers, including some Chinese. Although Māori challenged European settlement, New Zealand's European population expanded rapidly, due to migration and, later, natural increase. A population of probably

to Environmental and Biotic Changes', New Zealand Journal of Ecology XII (1989): pp. 115-129; Matt McGlone, 'Polynesian Deforestation of New Zealand: A Preliminary Synthesis', Archaeology of Oceania XVIII (1983): pp. 11-25.

9 The Future Eaters: An Ecological History of the Australasian Lands and People (London, 1996).

10 Anderson, 'A Fragile Plenty', pp. 19-34; McGlone, 'The Polynesian Settlement of New Zealand in Relation to Environmental and Biotic Changes', Nerw Zealand Journal of Ecology, XII (1989): pp. 115-129. 
fewer than 2,000 before 1840 grew by 1881 to well over half a million, reaching one million early in the new century. ${ }^{11}$

At the time organised European immigration commenced in the 1840s, native forest covered about half of the landscape. Although Māori settlement and various non-human events had wrought great environmental change in these islands, the scale and pace at which Europeans converted the New Zealand environment over the next decades was unprecedented. ${ }^{12}$ In only seventy years after Aotearoa officially became part of the British Empire, and in direct consequence of European settlement, New Zealand's forested area had shrunk to a quarter of the landmass. ${ }^{13}$

\section{The British tradition}

Despite significant other groups, for much of its history New Zealand tended to think of itself as thoroughly British. Settlers proudly declaimed New Zealand as the 'Britain of the South' or 'Better Britain', yet still reserved the epithet 'Home' for the place of their ancestry rather than where they actually lived..$^{14}$ Although it gained dominion status in 1907, New Zealand remained tied to, and dependent upon, the purse strings of Britain and its empire for many years afterwards. Heavy reliance on Britain for trade, and as a source of immigrants, did not lessen until the 1970s.

As indicated by the lamentation from Wilson quoted at the beginning of this article, the British tradition was frequently antipathetic to forests. This proved true across the British Empire. In the latter part of the nineteenth century New Zealand, Australia and Canada all gained a rapidly expanding settler population, largely British in origin. This settlement surge placed a heavy burden on local resources. Whether encountering New Brunswick's hemlocks and pines or New

11 J. Belich, Making Peoples: A History of the New Zealanders from Polynesian Settlement to the End of the Nineteenth-century (Auckland, 1996).

12 On Māori environmental change see, for instance, Atholl Anderson, and Matt McGlone, 'Living on the Edge - Prehistoric Land and People in New Zealand', in The Naïve Lands, ed. John Dobson (Melbourne, 1992), pp. 199-219; Belich, Making Peoples, pp. 38-56, 67-75; Anderson, 'A fragile plenty', pp. 19-34; on southern Māori resource use, see Atholl Anderson, The Welcome of Strangers: An Ethnohistory of Southern Maori A.D. 1650-1850 (Dunedin, 1998). On the rapidity of European environmental transformation, note Environmental Histories of New Zealand and Paul Star, 'Humans and the Environment in New Zealand, 1800 to 2000', in The New Oxford History of New Zealand, ed. Giselle Byrnes (Melbourne, 2009), pp. 47-70.

13 Michael Roche, 'The State as Conservationist', Environmental Histories of Nerw Zealand, p. 185.

14 Belich, Making Peoples. 
Zealand's kauri, British settlers found the forests unfamiliar. When growing in great profusion and over a large extent, most viewed forests as obstacles to farming, as something to be removed. The smell of burning frequently accompanied settlement, as did the sound of axe and the crash of falling trees. ${ }^{15}$ Settlers aimed to fashion farms from forests, an activity which in the moral economy of a Christian nation such as New Zealand met more than economic ends. Development upheld biblical notions of making land productive. It represented Christian endeavour and the fruits of labour in a new country. But its converse - leaving New Zealand as a howling wilderness - represented sin, as did wasting resources. ${ }^{16}$

Economically, gold became the principal export earner for New Zealand in the 1860s, but this represented something of a blip as the character of an economy reliant on meat, wool and dairy exports emerged by the later decades of the nineteenth century. These continued to dominate the New Zealand export market into the twenty first century. At first, farmers largely grazed sheep and cattle on the broad grasslands of Canterbury and Otago, pre-European in their origin. Later they directed their labours more to the 'opening up' of new land through the removal of native forest, a process focused on the North Island from the late nineteenth century as the dairying boom took off. But despite being an obstacle to settlement, wood also provided important raw material crucial to the household economy of most farms and for the internal development of New Zealand. Wood warmed houses and fenced in livestock, powered engines and provided comfort from the elements. In 1881, seven of every eight houses were wooden. ${ }^{17}$ Timber never approached pastoral produce as an external source of income. Tremendous economic, as well as cultural pressures, acted not so much to establish sustainable logging of native forests as to remove them altogether.

Against the background of removal, efforts began to conserve some of the forest, as a brief run-down of the legislative efforts demonstrates. Although most of New Zealand had large areas of forest, some regions, such as parts of Canterbury and Otago, had very few. From the 1850s to the 1870s, their provincial governments sought to address timber shortages by enacting cutting

15 See, Thomas R. Dunlap, Nature and the English Diaspora: Environment and History in the United States, Canada, Australia, and New Zealand (Cambridge, 1999).

16 James Beattie, and John Stenhouse, 'Empire, Environment and Religion: God and Nature in nineteenth-century New Zealand', Environment and History 13, no. 4 (2007): pp. 413-446.

17 On New Zealand's economic development see Tom Brooking, 'Economic Transformation', in The Oxford History of New Zealand, ed. Geoffrey W. Rice (Auckland, 1997 [second edition]), pp. 230-253. On its forest history see Rollo Arnold, 'The Virgin Forest Harvest and the Development of Colonial New Zealand', New Zealand Geographer XXXII (1976): pp. 105-126. 
restrictions, encouraging tree-planting and setting aside timber reserves. ${ }^{18}$ Timber shortages became so acute on the Central Otago goldfields, that its parliamentary representative in 1868 promoted tree-planting to ensure 'a constant supply of timber for pit props. ${ }^{19}$ In the next decade, the explosion of railway building consumed ever more cordage of New Zealand's forest resources and became a powerful motivation behind politician Julius Vogel's attempts to conserve forests with his 1874 New Zealand Forests Bill. Although subsequently revoked, some forestland was reserved by the 1877 Land Act, and still more after the failure of the 1885 State Forests Act to establish state forestry. The settlement 'push' by the Liberal government in the 1890s then sped up the destruction of forest and heightened existing fears of timber famine. At the same time, a move took place to reserve forest areas for scenic purposes. ${ }^{20}$

Throughout this period, forest resources continued to be exploited wastefully and haphazardly. Waste attracted the constant opprobrium of a number of individuals and organisations in New Zealand. This dated from the 1850s in Otago through to the writing of men of science such as T.H. Potts and W.T.L. Travers, to the work of artists, and to the Timber Conference of 1896 and the Forestry Commission of 1913. Although a Forestry Branch was created in 1896 under the Department of Lands and Survey (DLS), this focused exclusively on tree-planting, and its activities were treated as secondary in importance to those of its parent. Only after World War One did parliament create an autonomous State Forest Service (SFS). ${ }^{21}$

The stop-start nature of forest reservation and attempts to introduce practices of scientific forestry into New Zealand owed their origins to prevailing political, economic and environmental factors, as well as to global nineteenth century debates on the subject. ${ }^{22}$ In political and economic terms, laissez-faire attitudes

18 Paul Star, 'Place of Native Forest in New Zealand's Mental Landscape', in Australia's Ever-Changing Forests IV: Proceedings of the Fourth National Conference on Australian Forest History, eds. John Dargavel and Brenda Libbis (Canberra, 1999), pp. 85-98.

19 Charles O'Neill, NZPD, 7 October 1868, pp. 191-2.

20 Beattie, 'Environmental Anxiety in New Zealand, 1840-1941: Climate Change, Soil Erosion, Sand Drift, Flooding and Forest Conservation', Environment and History 9, no. 4 (2003): pp. 379-392.

21 For a detailed account of these developments, see Michael Roche, History of New Zealand Forestry (Wellington, 1990).

22 Scientific forestry embraced the idea that forests could be systematically harvested to ensure their best use, which today would be termed 'sustainable logging'. Jan Oosthoek, 'Themes in European Woodland History', in Australia's Ever-changing Forests V: Proceedings of the Fifth National Conference on Australian Forest History, eds. John Dargavel, Denise Gaughwin and Brenda Libbis (Canberra, 2002), pp. 34-6. 
to government lasted longer in New Zealand than they did in somewhere like India, where from the 1850s utilitarianism justified increasing government intervention in society and the establishment of more bureaucracies. ${ }^{23}$ Laissezfaire attitudes - combined with the significance of provincial government in New Zealand until the 1870s - accordingly restricted political willingness to establish large centralised forest bureaucracies. Forest policy was also shaped by geography and environmental factors. It made sense, for instance, to introduce tree-planting legislation into the provincial councils of the east-coast New Zealand provinces of Otago and Canterbury, because they suffered from a scarcity of forests exacerbated by colonial development.

These local factors also responded in different ways to the increasingly globalised literature on forest conservation. As early as 1868 the Scottish physician and naturalist, William Lauder Lindsay, who had visited New Zealand in 1861-2 for a few months, hoped for the establishment of a New Zealand Board of Forests to oversee the introduction of 'acclimatized trees of a hardier kind' - such as the Australian species blue gum (Eucalyptus globules), silver wattle (Acacia dealbata), stringy bark (of the Myrtaceae family) - to replace 'the old or primitive forests'. Although he advocated their protection, New Zealand trees, he believed, were 'doomed ... to ultimate decay and disappearance'. ${ }^{24}$ In principle, scientific forestry was introduced in New Zealand in 1874, but at best it remained under-funded and always of secondary importance to agricultural development. This was despite its promotion by a succession of visiting foresters and experts, and widespread reference to it by promoters in New Zealand.

New Zealand newspapers and journals regularly carried articles on developments and techniques in forestry from Europe and Asia, Australia and America. From the latter part of the nineteenth century, New Zealand foresters themselves also participated in global debates on forestry. As elsewhere, these included discussion of the effects of forests on climate, soil erosion and flooding, and demonstrated concern about a world-wide timber famine. While fears of timber famine focused on forest revenue and supply, those about climatic and hydrological deterioration held a deeper and darker economic and moral message, especially to New Zealand's agricultural lobby. Conservationists warned that if deforestation continued, New Zealand's productive economy, its 'smiling' fields,

23 Graeme Wynn, 'Pioneers, politicians and the conservation of forests in early New Zealand', Journal of Historical Geography 5, no. 2 (1979): pp. 171-188; Russell Dionne, and Roy MacLeod, 'Science and Policy in British India, 1858-1914: Perspectives on a Persisting Belief', ed. S. Irfan Habib and Dhruv Raina, Social History of Science in Colonial India (New Delhi, 2007), pp. 159-95.

24 W. Lauder Lindsay, 'On the Conservation of Forests in New Zealand', Journal of Botany British and Foreign VI (1868): pp. 40, 45. 
would be rendered a wilderness.

The prelude to the $1874 \mathrm{New}$ Zealand Forests Act included details of forest policies and problems in Victoria, South Australia, Ceylon and Germany, and elsewhere. ${ }^{25}$ These proved influential, first, because of the example set in the application of modern forestry techniques and policies to forest administration and, second, because of the salutary lessons they offered about the dangers of deforestation. All this extends both Richard Grove's emphasis on the worldwide exchange of forestry ideas and more recent interpretations on the nature of forestry in the British Empire. ${ }^{26}$ Grove, controversially, argued in 1995 that conservation developed as a result of European environmental encounters, particularly on tropical islands, rather than diffusing from Europe as existing models suggested. Conservation, Grove instead charged, spread to Europe from the colonies and from colony-to-colony. ${ }^{27}$ Gregory Barton's 2002 book, Empire Forestry and the Origins of Environmentalism, extended the work of Richard Grove on Indian forest conservation, picking up where Grove ended, in the 1860s. Barton demonstrated the importance of Indian models to the development of the empire forestry movement of the twentieth century. By contrast, Ravi Rajan's Modernizing Nature: Forestry and Imperial Eco-Development, 1800-1950, published in 2006, challenges Barton's analysis. Instead of Indian models, Rajan argues that Franco-German models retained their importance, their reception moderated by local factors as well as their continual exchange throughout this period. ${ }^{28}$ In light of such discussions, although this article examines the period up to the development of empire forestry rather than empire forestry itself, it nevertheless makes significant contributions to the arguments of both authors.

We note the importance of continental and Indian traditions of forestry, but highlight both their changing temporal significance and the importance of local factors beyond such influences. First, in New Zealand, the emphasis on

25 Appendices to the Journal of the House of Representatives (henceforth, AJHR), $1874 \mathrm{H}-5 \mathrm{~A}$, 1-7; H-5B, pp. 1-26. 2002).

26 Gregory Barton, Empire Forestry and the Origins of Environmentalism (Cambridge,

27 Richard H. Grove, Green Imperialism: Colonial Expansion, Tropical Island Edens and the Origins of Environmentalism, 1600-1860 (Cambridge, 1995). For different models he was criticising, note: Roy MacLeod, 'On Visiting the "Moving Metropolis": Reflections on the Architecture of Imperial Science', Historical Records of Australian Science 5, no. 3 (1982): pp. 1-16; MacLeod, 'From Imperial to National Science', ed. by Roy McLeod, The Commonwealth of Science: ANZAAS and the Scientific Enterprise in Australasia 1888-1988 (Melbourne, 1988), pp. 40-72.

28 S. Ravi Rajan, Modernizing Nature: Forestry and Imperial Eco-Development 1800-1950 (Oxford, 2006). Note, too, J.M. Powell, “Dominion over Palm and Pine”: The British Empire Forestry Conferences, 1920-1947', Journal of Historical Geography 33 (2007): pp. 852-877. 
Indian and Franco-German models shifted over time such that, for instance, by the late nineteenth century, American models were becoming particularly relevant. Second, while certain models were deemed useful for particular aspects of forestry, such as French dune reclamation, overall these introduced ideas had to be significantly adapted to local contexts. 'Local conditions', as historian of science David Livingstone has observed, 'pose[d] local problems needing local solutions. ${ }^{29}$ An illustration of this is the example of J.R. Hacket. In 1883, he presented a paper to the Nelson Philosophical Institute entitled 'Forest Culture in Germany with suggestions for the future cultivation of Forests in New Zealand'. Although recognising the 'highest scientific attainments' of German forestry and detailing its management practices, Hacket acknowledged that 'European treatment of the forest is however not entirely applicable to N.Z. [sic] bush'. He explained New Zealand native forests generally die if thinned and are particularly susceptible to fire damage. He also contended that, unlike Germany and France, no New Zealand legislation restricted the wandering of cattle, which detrimentally impacted on native forests. Moreover, when compared to German forests, New Zealand trees grew faster and had greater yields, while fewer trees were lost to hoar frosts and wind damage. ${ }^{30}$ Third, this article provides a practical instance of forest conservation that can usefully add to Rajan's study, which presented an intellectual history of the exchange of forestry ideas without an examination of the introduction of such ideas. Fourth, although we agree with Barton's emphasis on the importance of Indian models, at least for the 1860s to 1870s in New Zealand, we also wish to show that these influences simultaneously sat alongside other forestry models and traditions. Fifth, we do not accept Barton's linear model for the development of forestry, which he contends moved from Germany to India to the British colonies and thence to the United States. Instead, we demonstrate different influences, sometimes simultaneously, shaped forest policy and forest conservation in New Zealand. Expressed another way, while following the work of David Lambert and Alan Lester that 'ideas, practices and identities developed trans-imperially as they moved from one imperial site to another', we also stress the importance of the uniqueness of such local sites in the making of forest policy. ${ }^{31}$ In New Zealand, however, the process was more complicated: forestry

29 Livingstone, Putting Science in Its Place, p. 45.

30 J.R. Hacket, 'Forest Culture in Germany with suggestions for the future cultivation of Forests in New Zealand', Read 14 December 1883, Nelson Philosophical Society, MU156, R-1M03131D, Te Papa Tongarewa/The Museum of New Zealand, p. 8.

31 David Lambert and Alan Lester, 'Imperial Spaces, Imperial Subjects', in Colonial Lives Across the British Empire: Imperial Careering in the long nineteenth Century, eds. David Lambert and Alan Lester (Cambridge, 2006), p. 2. 
ideas did not influence different places successively as Barton maintains. In New Zealand forestry ideas were being continually exchanged between different parts of the world over this period, both within the Empire and beyond. This pattern more closely resembles that identified by Ravi Rajan in Modernizing Nature.

A number of groups and influences may be identified as contributing to the development of forest conservation and forestation. In the eighteenth and nineteenth centuries, Scottish-trained doctors played a significant role in promoting forest conservation in the East India Company. ${ }^{32}$ They were also influential in the creation of forest policy in New Zealand in the 1860s and 1870s, but without having the impact on forest policy development similar groups had in India. Until around the mid-nineteenth century in particular, Scottishtrained medics took a lead in India in promoting the application of science for the betterment of humanity and colonisation. They believed museums, botanical gardens and forest conservation materially advanced British colonisation by acting as centres for the acclimatisation, investigation and utilisation of plants and animals. As the Scottish-trained physician Lindsay emphasised, for the New Zealand province of Otago the 'natural sciences' were 'a distinct power' and occupied 'a distinct place in colonization' (emphases in original). ${ }^{33}$

Another Scottish medic, who lobbied for similar causes, was Sir James Hector. As New Zealand's leading scientist in the nineteenth century, Hector earned his medical degree (which included botany papers) at Edinburgh University only a few years after Lindsay. He advanced forest conservation in New Zealand, sharing with Lindsay a desire to see the application of science to natural resources reap economic and social rewards. To this end, Hector published surveys of New Zealand's forests and stressed forest conservation for the protection of the nation's climate. Aside from medics, a number of other Scots were prominent in early New Zealand forest conservation, most probably as a result of experience of Scottish plantation forestry. Such individuals included Southland's first Inspector of Forests, Duncan McArthur and, later, Alexander Bathgate, who helped establish Arbor Day, the New Zealand Forestry League, and New Zealand's first urban conservation society. Many Scottish-trained nurserymen and gardeners also found work in the colony. ${ }^{34}$

32 Grove, Green Imperialism; James Beattie, 'W.L. Lindsay, Scottish Environmentalism, and the "Improvement" of nineteenth-century New Zealand', in Landscape/Community: Perspectives from New Zealand History, eds. Tony Ballantyne and Judith A. Bennett (Dunedin, 2005), pp. 43-56.

33 William Lauder Lindsay, The Place and Power of Natural History in Colonization: with special reference to Otago; being portions of a lecture prepared for, and at the request of the "Young Men's Christian Association" of Dunedin (Dunedin, 1862), pp. 5, 7.

34 Beattie, ‘W.L. Lindsay, Scottish Environmentalism', pp. 43-56. 
A strong South Asian influence on forestry policy in New Zealand existed in the 1870s and 1880s, reflected by the appointment of Captain (later Colonel) Inches Campbell Walker from Madras's forest department, the activities of a significant number of ex-Indian civil service and military in New Zealand's parliament who lobbied for forest conservation, and the exchange of ideas and information in printed and private letters. ${ }^{35} \mathrm{By}$ the turn of the twentieth century the dominant model had shifted to the recently-established United States Forestry Service (USFS), with its concurrent emphasis on soil erosion concerns rather than those relating to climate. By then, too, the likes of David Hutchins, who had trained at the well-known École Nationale des Eaux et Forêts in Nancy, France, and practised as a forester in India, Africa, and Cyprus, typified not only the increasingly internationalised nature of 'imperial forestry' but also the diverse influences coming into play on New Zealand forest policy by this period. ${ }^{36}$

\section{Climatic forestry}

For much of the nineteenth century, the climatic effects of deforestation received a great deal of attention from foresters and conservators, helping to justify forest conservation in many areas in the world. ${ }^{37}$ Many scientists believed that trees influenced climate. Their leaves, some argued, intercepted saturated air, causing it to condense and fall as rain, while forested land moderated summer and winter temperature extremes. Given these considerations, forest removal threatened to lessen rainfall and increase temperatures. ${ }^{38}$

Climatic ideas, first voiced in parliament in 1868, were an important argument for the conservation of New Zealand's forests from the early 1860s, becoming commonplace in scientific and parliamentary circles from the 1870s.

35 See, James Beattie, 'Tropical Asia and Temperate New Zealand: Health and Conservation Connections, 1840-1920', in Asia in Making of New Zealand, eds. Henry Johnson and Brian Moloughney (Auckland, 2007), pp. 36-57.

36 W. Schlich, 'Forestry in the Dominion of New Zealand', New Zealand Journal of Science and Technology 1, no. 4 (1918): pp. 201-10; Michael Roche, 'Sir David Hutchins and Kauri in New Zealand', in Araucarian Forests: Australian Forest History Society Inc., Occasional Publication No. 2, Australian Forest History Society: Kingston, ed. John Dargavel (Australia, 2005), pp. 33-40.

37 See, for instance, Michael Williams, Americans and their Forests: A Historical Geography (Cambridge, 1989), pp. 144-5, 383-4; Grove, Green Imperialism, pp. 380-473; Joachim Radkau, Natur und Macht: Eine Weltgeschichte der Umwelt (München, 2000), pp. 245-54; Herbert Killian, 'Entwicklung der staatlichen Forst aufsicht', in Österreichs Wald: Vom Urwald zur Waldwirtschaft, ed. Österreichischer Forstverein (Vienna, 1994), pp. 439-53.

38 Beattie, 'Climate Change, Forest Conservation and Science: A Case Study of New Zealand, 1860s-1920', History of Meteorology V (2009): pp 1-18. 
Campbell Walker, as New Zealand's first conservator of forests, was a vocal and impassioned supporter of state forestry in New Zealand. Conservation would, he charged, bring profit and safeguard both timber supply and rainfall. He cited the works of many overseas scientists - including Alexander von Humboldt and Joseph Boussingault - to lend authority to his proposals and quoted the American conservationist George Perkins Marsh, whose classic work of 1864 highlighted the baneful ecological effects of deforestation. Many politicians and farmers in New Zealand echoed Campbell Walker's proposals in the nineteenth century. So also did the French forester A. Lecoy, the civil engineer F. S. Peppercorne, and Augustus Hamilton, the ethnologist, biologist and future Director of the Colonial Museum (1903-1913). ${ }^{39}$

In this period, soil erosion concerns commonly appeared alongside climatic arguments. Forests were also thought to regulate the flow of water into rivers and streams, thereby preventing disastrous floods and the removal of fertile soil. A forceful proponent of forestry was W.T.L. Travers, a New Zealand politician, lawyer and naturalist. In 1870, he protested the forests being 'recklessly and improvidently burnt' without regard either for 'the immediate effects which such destruction may produce upon climate' or for soil protection. Deforestation turned rivers into 'raging torrents', he claimed, washing away soil and choking waterways with debris. ${ }^{40}$

By the early twentieth century scientific arguments focused more on the links between deforestation, soil erosion and flooding. In this period, overseas scientific evidence - principally from the United States - gained a receptive audience in New Zealand forestry circles. While emphasising the soil erosion-deforestation connection, this scholarship also subjected the forests-climate connection to sustained criticism. New Zealand conservationists considered these ideas seriously because of growing environmental problems in New Zealand. From the 1900s land degradation developed, strengthening fears of soil erosion. In this period too, high country burning and rabbit infestations accelerated calls for the afforestation of highlands and the reservation of existing forests. By the 1920s, forestry for profit - but also to prevent flooding and soil erosion, and increasingly fire - assumed importance in the new State Forest Service. By the 1930s, soil

39 Captain Inches Campbell Walker, 'State Forestry: Its Aim and Object', Transactions and Proceedings of the Nerw Zealand Institute (henceforth TNZI) IX (1876): pp. 187-203; also I. Campbell Walker 'The Climatic and Financial Aspect of Forest Conservancy as applicable to New Zealand', TNZI IX (1876): pp. xxvii-xlix; Campbell Walker, 'Report of the Conservator of State Forests', $A p$ pendices to the Journal of the House of Representatives (AJHR), (1877), C-3, pp. 12-49.

40 W.T. L. Travers, 'On the Changes Effected in the Natural Features of a New Country by the Introduction of Civilized Races', Part III, TNZI 3 (1870): pp. 326-7. 
erosion received belated scientific attention. ${ }^{41}$

\section{Forestation and desertification}

Another lesser activity of the SFS involved the protection and restoration of coastal and inland areas imperilled by shifting sands, an acknowledged problem from quite early on in New Zealand's colonisation that gained greater importance - or at least was encountered more frequently - with an expanding population. James Cook (1728-1779) named New Zealand's Northland coast the 'Desert Coast', and confided to his journal that

no Country upon Earth can looke more barren than the land about this Bay doth [.] it is in general low except the mountain just mentioned and the Soil to all appearance[s] nothing but white sand thrown up in low irregular hills lying in narrow ridges parrallel [sic] with the Shore. ${ }^{42}$

In 1872, C.D. Whitcombe presented an alarming picture of the growth, extent and devastating potential of sand drift at his address to the Wellington Philosophical Institute. 'Everyone can see with their own eyes', he declared, 'the rapidity with which ... land is drifting in this province [Taranaki] and elsewhere in the colony from fruitfulness to desolation'. ${ }^{43}$

Anxieties about sand drift increased into the nineteenth century and followed a distinct pattern. Each writer emphasised the devastation wrought by spreading sands. Throughout the nineteenth and early twentieth centuries, the successful example of French dune stabilisation was constantly upheld as the model New Zealand should follow, while New Zealand foresters also sought out advice from French foresters on the matter. This attitude was typified by one New Zealand author who praised the French success in the Gulf of Gascony, which had 'completely arrested' the 'process of devastation' caused by sand drift, whereby 'thousands of acres of former sand-waste now yield a handsome revenue, and

41 Michael Roche, Land and Water: Water and Soil Conservation and Central Government in New Zealand, 1941-1988 (Wellington, 1994), pp. 25-6; Kenneth Cumberland, Soil Erosion in New Zealand: A Geographic Reconnaissance, $2^{\text {nd }}$ ed. (Wellington, 1947), pp. 158-64.

42 James Cook, 17 August 1770, in 'James Cook's Journal of Remarkable Occurrences aboard His Majesty's Bark Endeavour, 1768-1771', National Library of Australia, South Seas Voyaging Accounts http://southseas.nla.gov.au/index voyaging.html (accessed 20 October 2009).

43 C. D. Whitcombe, 'On the Reclamation of Land devastated by the encroachment of sand', TNZI V (1872): p. 108. 
support a considerable population'. ${ }^{44}$

After constant local attempts to remedy dune erosion, the New Zealand Parliament passed the Sand-drift Act (1903). This legislation allowed New Zealand's Minister of Lands to formally identify an affected area and to authorise its reclamation by local authorities, which then could recover costs through rates levied on the reclaimed land. The problem of sand encroachment was that only the population of relatively densely settled areas - those with a sufficiently large tax base in other words - could afford the costs of arresting sand drift. Farming areas, over which much of the sand was spreading, remained particularly vulnerable, as funds were simply unavailable to arrest this problem. The problem, first identified in parliament by Robert McNab, ${ }^{45}$ was confirmed by Leonard Cockayne's 1909 report on sand dunes, which pointed out the still vast areas of drifting sands. Hampered by insufficient funds, first the SFS (in the 1920s) and then the Public Works Department (1930s-1951) undertook some reclamation schemes. ${ }^{46}$

As the settlers were removing native timber, so were they replacing it with introduced species. Tree-planting accompanied the mania for acclimatisation that came with the settlers. Mostly it was undertaken by private individuals, though the state also intervened to promote its development at various local levels. Only with the creation of the first fully functioning state organ for forestry - the Forestry Branch, in 1896 - did state afforestation gain much substance, contributing some 60,000 acres of forest by $1918 .{ }^{47}$

Nevertheless, there was some tree-planting legislation enacted from the 1850s through to the 1870s in Canterbury and Otago. Confirming the importance of locality in environmental history, as early as 1858 the South Island province of Canterbury enacted a tree-planting act, designed to encourage the spread of trees. ${ }^{48}$ In 1872, it was adopted on a nationwide basis. ${ }^{49}$ Most parliamentarians accepted the need for such a measure, particularly in the relatively treeless provinces of Otago and Canterbury, where areas of forest did not match with areas of settlement. Indeed, most of the takers of this scheme came from these

44 T. Kirk, 'Notes on the Plants Best Adapted for the Reclamation of Sand Wastes', TNZI VI (1873): p. 54.

$45 \mathrm{McNab}, 28$ September 1903, NZPD: p. 8.

46 Peter McKelvey, Sand Forests: A Historical Perspective of the Stabilisation and Afforestation of Coastal Sands in New Zealand (Christchurch, 1999), pp. 41-8.

47 Michael Roche, Forest Policy in New Zealand: An Historical Geography, 1840-1919 (Palmerston North, 1987), p. 54.

48 'The Planting of Forest Trees Ordinance 1858', The Ordinances of the Province of Canterbury, Session 10, October to December 1858.

49 See 'An Act to amend "The Forest Trees Planting Encouragement Act, 1871", Statutes of New Zealand (Wellington, 1872), pp. 283-5. 
two provinces. ${ }^{50}$ The Act awarded planters of trees either a free grant of two acres for every acre of land planted in trees or a land order not exceeding $£ 4$ that was redeemable later. ${ }^{51}$ This legislation enshrined the principles of tree-planting for fuel, construction, climatic control and soil quality and, interestingly enough, provided a model for similar legislation adopted in South Australia.

One fascinating individual who took full advantage of the regulations was an 'old warrior' from India, Colonel de Renzie James Brett (1809-1889). With a 'fiery, impulsive' temperament, Brett was a colourful and energetic parliamentarian and farmer in Canterbury as well as an enthusiastic supporter of forest conservation along Indian lines. Taking advantage of the recent tree-planting legislation, Brett designed a plantation which reflected his eccentric personality and the impact of India on his life. His plantation replicated the displacement of his troops during the Indian revolution of 1857 when he commanded an attack on the fort of Kirwee (now Karwee) in the Deccan plains, an act he also commemorated through naming the region he settled Kirwee. ${ }^{52}$

Brett's scheme underlines that tree-planting fulfilled many aims. Trees enhanced the beauty of an area, reminded people of their place of birth, provided fuel, building materials and shelter, and in some circles were thought to protect climate and waterways. The politician and farmer Josiah Firth typified New Zealand's private tree-planting efforts when he recommended the planting of eucalyptus and conifer species. Most writers of this time favoured fast-growing pines, with universal support for Pinus insignis. ${ }^{53}$ Popular as a shelterbelt in the 1870s, under the new name of Pinus radiata, it is now a ubiquitous feature of the New Zealand landscape.

For some nineteenth century New Zealanders, afforestation in non-New Zealand trees appeared the only measure that could ensure a constant supply of timber. Scientific theory and experience lent credence to the notion that New Zealand's native trees would soon be extinct. Many nineteenth century scientists, like Charles Darwin, Joseph Hooker and Alfred Russel Wallace, believed that the 'displacement' of native plants, animals and humans by European or northern species was inevitable. The belief was reinforced by perceptions of the slower

50 NZPD, 15 September 1871, pp. 459-62; 8 November 1871, pp. 918-19.

51 'An Act to amend "The Forest Trees Planting Encouragement Act, 1871," p. 284. On which see Paul Star, 'Tree-planting in Canterbury, New Zealand, 1850-1910', Environment and History 14, no. 4 (2008): pp. 563-582.

52 William Ellison Burke, 'Reminiscences of Old Canterbury', qMS-0333, ATL, p. 51; Beattie, 'Making Home, Making Identity: The Role of Asian Garden-Making in New Zealand Settler Culture, 1850s-1930s', Studies in the History of Gardens $\mathcal{F}^{\circ}$ Designed Landscapes (forthcoming).

53 J. C. Firth, 'On Forest Culture', TNZI VII (1874): p. 195. 
growth-rates of New Zealand species compared to exotics. In 1874, the New Zealand parliamentarian John Sheehan employed this theory to argue that 'the same mysterious law which appears to operate when the white and brown races come into contact ... by which the brown race, sooner or later, passes from the face of the earth - applies to native timber'. ${ }^{54}$ For Sheehan, reservation was pointless since New Zealand's trees would surely die out. Although most New Zealand scientists only firmly rejected displacement theory after 1900, public rejection of it took longer. Displacement theory therefore encouraged afforestation with exotics, rather than with native trees.

\section{New arguments in the $1890 \mathrm{~s}$}

Other global trends, not intrinsically to do with forests, also profoundly impacted on New Zealand forest policy. By the 1890s these included aesthetics, tourism, ecology, religion and nationalism. ${ }^{55}$ In contrast to scientific forestry, the influences usually supported the reservation of areas for non-economic motives, although economic considerations also played a strong role. In 1874, for instance, the politician and artist William Fox cited Yellowstone National Park as a precedent for New Zealand's Government, were it to reserve the 'Hot Springs District' on North Island's volcanic plateau for its tourist and bathing potential. To Fox the area was 'almost worthless for agricultural or pastoral, or any similar purposes'. ${ }^{56}$ And when the Minister of Land, John McKenzie, introduced the Tongariro National Park Bill in 1893 he likewise stressed that the land could have no other benefit than as scenery. ${ }^{57}$

Scenic appreciation strongly reflected the cultural background of the great majority of New Zealand's parliamentarians who were of European origin (Pākehā). Unsurprisingly, those parts of New Zealand's landscape which corresponded closest to what Europeans considered attractive received the greatest support for conservation. Right from the first days of settlement, romantic conventions of beauty fired aesthetic appreciation of New Zealand forests in visual and written form..$^{58}$ In 1858 , for instance, John Logan, Secretary

54 NZPD, 31 July 1874, pp. 350-3.

55 Paul Star, 'Native Forest and the Rise of Preservation in New Zealand (1903-1913)', Environment and History 8 (2002): pp. 275-294. For a sustained and fascinating discussion of this period, see Geoff Park, Theatre Country: Essays on Landscape and Whenua (Wellington, 2006).

56 AJHR 1874 H-26, pp. 1-5.

57 John McKenzie, NZPD, 7 July 1893, p. 309.

58 Beattie, 'Wilderness Found, Lost and Restored: The Sublime and Picturesque in New Zealand, 1830s-2000s', in The Future of Wilderness in Aotearoa New Zealand, eds. Richard Reeve and 
to the Otago Provincial Council, complained of squatters in Dunedin's Town Belt who had 'done irreparable damage by cutting down a considerable portion of the Bush on the Belt which served to beautify the place and which hitherto had been carefully preserved by Mr. Chapman and myself respectively'. ${ }^{59}$ Scenic appreciation also frequently had its inspiration in Christianity. Sheer, steep, angular mountains, preferably experienced in a storm, gave delight and encouraged solemn contemplation of God's awful magnificence through the sublime, no less in New Zealand than in Europe. ${ }^{60}$ As well as the sublime, colonists could appreciate those parts of New Zealand's scenery which corresponded to other aesthetic notions such as the picturesque or beautiful. Otago's (initially) bush-clad gently rolling hills surrounding its harbour commonly elicited the picturesque while ploughed fields and rural husbandry evoked the pastorale. Although scenery appreciation only became a widespread primary motive for conservation in the 1890s, it had nonetheless inspired the preservation of limited areas and the design of urban parks. As Premier Richard Seddon argued when introducing the Scenery Preservation Bill to Parliament in 1903, 'beautiful bush scenery' gave New Zealand's mountains 'their most potent attractions' ${ }^{61}$

The impact of Christianity - for too long either associated with environmental destruction or by and large ignored - also shaped environmental attitudes and use. Recent research reveals that while most settlers interpreted the account of Genesis as legitimising environmental change and, as they saw it, improvement, such attitudes also co-existed with respect for nature and an ethic of stewardship. When it became apparent that the intended benefits of environmental improvement had actually wrought considerable damage, 'concerned Protestant community leaders deployed Christian discourse, biblical images, and Protestant ethics along with utilitarian and scientific arguments to mobilize environmental concern and a conservationist conscience'. ${ }^{62}$ Put simply, the prevailing attitude was of use, not abuse.

Indeed, the Bible was invoked to provide terrifying examples of the follies of deforestation, examples that many proponents of forest conservation drew upon to push their cause. In 1873, for instance, Charles O'Neill listed reasons against deforestation which appeared like Biblical injunctions: 'Ali Pacha burnt

Mick Abbott (Nelson, forthcoming).

59 John Logan to Deputy Superintendent, Royal Terrace, 10 August 1858, Otago Provincial Government, Microfilm 414/8, no. 244, Hocken Library: Dunedin, New Zealand.

60 Beattie, 'Romanticism, Art, Health and Conservation in Otago, 1840-1860', Settlers' Nerwsletter 81, no. 1 (2007): pp. 1-4.

61 NZPD, 28 October 1903, p. 88.

62 Beattie and Stenhouse, p. 413. 
down the forests ... and then came famine and drought'; the Russians changed the Caucasus' climate, and 'the land became barren, drought ensued'. The moral imperative was clear: it was a Christian duty to prevent land becoming waste. ${ }^{63}$ The Bible indicated that God had given humanity dominion over nature, but also encouraged the care and wise management of resources. In the 1900s, this background explains settler John McLay's criticism that 'the cruel Ruthless hand of man should destroy God's beautiful work - all for the lust of money that sends so many to destruction'. ${ }^{64}$

By the turn of the twentieth century New Zealand's beautiful bush scenery was attracting increasing numbers of tourists, both domestic and foreign. Tourists appreciated 'unspoilt' scenery, especially uncut forests. In Canada from the 1880s, the Canadian Pacific Railway brought both tourists and a tidy profit to its Rocky Mountains National Park. ${ }^{65}$ A similar aim underlay the creation of a Department of Tourist and Health Resorts in New Zealand in 1901. Its first superintendent, Thomas Donne, had formerly managed Auckland Railways. His appointment coincided with the construction of the main trunk line between Wellington and Auckland, which for some of its length followed the edge of the recently-created Tongariro National Park. Donne, realising its value, observed that the line would 'pass through some magnificent areas of forest, which, if preserved in its primeval beauty contiguous to the railway, will afford a great attraction to travellers'. ${ }^{66}$ Areas of native forest spared from logging under the Scenery Preservation Act 1903 were initially administered by the Tourist Department.

By the late nineteenth century ecological ideas also made a special imprint on New Zealand forest conservation. Through the German translation of Eugenius Warming's Plantesamfund in 1895, ecology began to spread through the world's scientific circles. Plantesamfund encouraged forest protection by increasing understanding of plant communities and their significance. Although plant ecology's influence on the environmental movement in Britain was slight, it made extraordinary inroads into New Zealand scientific and environmental policy circles following its early espousal by Leonard Cockayne. ${ }^{67}$ Cockayne advised

63 O'Neill, NZPD, 1 October 1873, p. 1545.

64 John McLay, 'My Young Life in Otago: Part One of Reminiscences' in the John McLay papers, typescript, Otago Settlers' Museum, p. 4.

65 Janet Foster, Working for Wildlife: The Beginning of Preservation in Canada (Toronto, 1978), p. 17; David Young, Our Islands, Our Selves: A History of Conservation in New Zealand (Dunedin, 2004), pp. 109-38.

66 AJHR $1902 \mathrm{H}-2$, p. 21.

67 Peter J. Bowler, The Fontana History of the Environmental Sciences (London, 1992), p. 377. On ecology in New Zealand, see Paul Star, 'Ecology: A Science of Nation? The Utilisation of Plant Ecology in New Zealand, 1896-1930', Historical Records of Australian Science 17, no. 2 (2006): 
the government on Tongariro National Park in 1908, served on the Forestry Commission in 1913, was a founding vice-president of the Royal Forest and Bird Protection Society, and produced many ecological reports for the government.

Cockayne put ecology to good use and fused it with nascent settler nationalism, becoming probably the first New Zealander to argue that scenery 'does not depend merely upon geological or geographical characteristics ... but upon the plant covering of the place in question'. ${ }^{68}$ According to him, the most distinctive feature of New Zealand was not its mountains but its native flora. By highlighting New Zealand's 1800 species of indigenous flowering plants, 84 percent of which were endemic and its trees among the largest and longest living of any in the world, Cockayne set in motion a strong argument for protection of native forest or 'bush' not only for its value to tourism and science, but also for its significance to national identity. ${ }^{69}$ By 1913 the protection of native forests - the 'cathedrals' of New Zealand - had become a 'patriotic' endeavour for its Pākehā population, though often at the expense of Māori (see below).

This endeavour was possible because in the 1890s an increasingly urbanised, New Zealand-born European population was coming to view the bush with its natural inhabitants as an important national icon. Nationalism and forests received a boost on 4 August 1892 when New Zealanders celebrated their first national Arbor Day. Accompanied by the regalia of mayoralty and the singing of patriotic songs, schoolchildren took centre stage - as they would continue to - in the planting of native and introduced trees, a symbolic act of moral and community cultivation as much as an arboricultural endeavour. The Lakes District in Otago had honoured Arbor Day earlier, celebrating the planting of trees with marches, music and the munching of lollies and cakes. ${ }^{70}$ Trees and tree-planting thus became a popular focus in community cultural events.

Art visualised nationalist sentiment in another way through representations of a nation's flora and fauna. In Australia, painters of Melbourne's Heidelberg School depicted lives played out against a backdrop of eucalyptus trees. In the United States, as indeed in many other recently colonised lands, natural heritage in the form of national parks substituted for the cultural heritage of Europe's castles and cathedrals. ${ }^{71}$ This also occurred in New Zealand from the 1880s.

pp. 197-207.

68 AJHR, 1908, C-8, p. 2.

69 Paul Star, and Lynne Lochhead, 'Children of the Burnt Bush: New Zealanders and the Indigenous Remnant, 1880-1930', in Environmental Histories of New Zealand, eds. Eric Pawson and Tom Brooking (Auckland, 2002), pp. 128-30.

70 Otago Witness 11 August 1892, p. 16; 10 August 1893, p. 22.

71 See Tim Bonyhady, The Colonial Earth (Melbourne, 2001); Dunlap, Nature and the 
Artist Alfred Sharpe, for instance, extolled the colony's environment as 'special and unique', urging its artists to 'strive to reproduce Nature here as she is [rather than through European artistic conventions], ere her originality disappears before the combined effects of advancing civilization and imported vermin and vegetation'. In Auckland in the 1870s and 1880s, Sharpe's paintings of altered landscapes provided visual evidence in support of his written campaigns for forest conservation. ${ }^{72}$

Tongariro became New Zealand's first national park in 1894. Between its creation and extension in 1922, two new types of major forest reservation took place. Particularly in the decade from 1903, many large and remote areas of forest (such as Fiordland) as well as smaller areas closer to settlements became classified as national parks or scenic reserves. By 1914, over two million acres had the status of either one or the other.

In the thirty years after 1890, a fundamental divergence in New Zealand conservation also took place. Colonists differentiated 'preservation' (leaving a forested area alone and 'untouched') with 'conservation' (in the sense of sustainable forestry). This parallels the dichotomy of approach to native forests elsewhere, most famously in the American context with the parting of the ways between the transcendentalist John Muir and forester Gifford Pinchot. The distinction is useful in New Zealand, but it does not apply in every case and must be used carefully. It is, for instance, relevant to an understanding of the conflict over Waipoua kauri forest in northern New Zealand. State foresters wanted the area logged, but faced spirited opposition by members of the Waipoua Forest Preservation Committee (founded in 1932) who wished to see the area remain un-milled. ${ }^{73}$

\section{Intrinsically local factors}

New Zealand's forest history, we have argued, has to be understood within a global framework. Particularly after the First World War a larger area - nearly seven million acres by 1920 - was reserved as state forest or provisional state forest and entrusted to a vigorous new forestry department. Worldwide, the First World War acted as a wake-up call to politicians and foresters on the economic and strategic importance of possessing an internal timber supply. Such a resource would be unaffected by any loss of timber-producing allies or blockage of timber

English Diaspora.

72 Roger Blackley, The Art of Alfred Sharpe (Auckland, 1992), p. 46. On his environmental ideas, see James Beattie, 'Alfred Sharpe, Australasia, and Ruskin', Journal of New Zealand Art History XXVII (2006): pp. 38-56.

73 See Roche, History of New Zealand Forestry, pp. 405-14. 
supplies. Yet global ideas, as we have illustrated, operated at a local level, and local-level circumstances led to choices about which particular ideas to pursue or reject.

Individuals had a particularly strong impact on New Zealand forest policy. This may have been the case everywhere, in a world where the majority displayed little interest in forestry. New Zealand's relatively low population and small colonial bureaucracy may, however, have enhanced the influence of individuals when compared to other states with a degree of self-government. Arguments about ecology - bearing in mind that Warming's work was not even translated into English until 1909 - would have had no early circulation in New Zealand, and even then would probably have found little practical application, were it not for Cockayne. How far would forest legislation have progressed in 1874 and 1885 were it not for the domineering presence of Vogel, whose fascination with forestry was thought eccentric, but whose wishes were gratified to some extent so long as he remained in government? Parliament passed Vogel's legislation when he was in power, but did not support it when he was in opposition. The relatively underdeveloped nature of state forestry activities in New Zealand - in parallel with other settler societies such as Australia and Canada - suggests the limitations of more democratic practices of government in determining forest areas. In all three cases, the overriding interests of settlers were reflected spatially, politically and ecologically in the emphasis placed on land development. Compare these settler societies with India, where by the twentieth century a small cadre of dedicated forestry officials, coupled with the autocratic powers of a colonial state, achieved a remarkable degree of control over the forests of the Indian sub-continent. ${ }^{74}$

Landscape also led to localised variations in forestry techniques. This reminds us that, particularly in environmental history, natural boundaries can be at least as significant as political ones. In Auckland Province, sawyers sent logs tumbling down rivers, then processed them on site or floated them to far away mills. This often resulted in wastage. By contrast, in the South Island prior to the development of an extensive steam railway network, sawyers would often transport logs to port or market on skids or by tramway. The mountainous landscape of many parts of New Zealand and the inaccessibility of some forests - most notably in Fiordland - also prevented both logging and agriculture in some areas. Instead, it encouraged people to value these forests in other ways, as tourist attractions or national icons. Steep terrain, moreover, increased national awareness of soil erosion and, in the nineteenth century, highlighted the need for climate reserves.

74 On which, see Rajan, Modernizing Nature; Ramachandra Guha, The Unquiet Woods: Ecological Change and Peasant Resistance in the Himalaya (Delhi, 1991). 
Overall, the nature of the indigenous forest flora itself had perhaps the greatest impact on forest policy. As noted earlier, foresters found New Zealand's trees 'of much slower growth than those used in forestry operations the world over'. New Zealand's 1913 Forestry Commission considered that, except for native beech, New Zealand forests 'cannot regenerate sufficiently quickly to allow them to be kept as permanent forests yielding a succession of crops'.$^{75}$ It therefore appeared logical to meet future timber needs through extensive plantation of exotics - and of Pinus radiata in particular - rather than of natives. And until these plantations matured, it made every sense to clear-fell native forest, especially because cleared land could be settled and converted to farming. Exotic afforestation thus dominated New Zealand's forestry industry and bucked the trend in international forestry, which instead stressed the importance of sustainable forestry of indigenous species. Sir David Hutchins, possibly the most experienced forester in the British Empire at the time, spent the last years of his life in New Zealand (1915-20) and favoured an indigenous forestry programme. So, initially, did Macintosh Ellis, New Zealand's first Director of Forests from 1919, though he changed his mind later upon close analysis of the evidence. Sustainable utilisation of native timbers also would have seemed appropriate for a new nation that had begun to value its native productions and which now felt their management was possible.

Native forest restoration was easier, in fact, than most settlers thought, though it remains true that most native species do not regenerate so readily as many overseas species. Since 1925, increasing reliance on exotic afforestation has emerged as the most remarkable aspect of New Zealand forestry. By 2000, the entire native forest remnant was considered representative of iconic New Zealand - and very largely removed from all possible milling. There is now no production forestry using any indigenous species on any state-owned land. ${ }^{76}$

\section{Existing and Future Research}

Worldwide forest studies dominate environmental historiography and represent some of the earliest examples of this genre. Everything from their political iconography, mythic potential and economic uses, to their acclimatisation, experimentation and use in construction and medicine - plus more besides has been studied. ${ }^{77}$ The same variety of approach is true of forest studies in New

75 AJHR, 1913, C-12, pp. xlv, xii.

76 Young, pp. 205-40.

77 Note, for instance, Denis Cosgrove, and Stephen Daniels, eds., The Iconography of Landscape: Essays on the Symbolic Representation, Design and Use of Past Environments (Cambridge, 1988); Simon Schama, Landscape and Memory (London, 1996); Williams, Americans and their Forests; Ashley 
Zealand.

One can argue that, while precedents existed, the arrival of environmental history in New Zealand was marked by the publication, in 2002, of the interdisciplinary Environmental Histories of New Zealand edited by Eric Pawson and Tom Brooking. ${ }^{78}$ Other collections of New Zealand environmental history have quickly followed, while the only environmental history journal in New Zealand, ENNZ: Environment and Nature in New Zealand, has carried several articles on the topic. ${ }^{79}$ Studies of forest histories predate the establishment of environmental history as a discipline in New Zealand and have been characterised by useful national analyses, more fine-grained local studies, and biographies of those interested in forestry. They generally fall into two groups: those produced by professional scholars, and those by forestry professionals and other scientists. ${ }^{80}$ Historical geographer Michael Roche, for example, has published excellent overviews of the development of private and state forestry in New Zealand, while Graeme Wynn provided a pioneering - and still relevant - analysis of state forest conservation in two articles from 1977 and $1979 .{ }^{81}$ Other studies have focused on individuals or themes significant to forestry, or, in the case of a number of academic theses, on fauna and flora conservation. ${ }^{82}$ In addition, the Australian

Hay, Gum: the Story of Eucalyptus and their Champions (Sydney, 2002); Richard Drayton, Nature's Government: Science, Imperial Britain, and the 'Improvement' of the World (New Haven and London, 2000). 78 (Melbourne, 2002).

79 Note, for instance, the special issue on New Zealand of Environment and History 9, no. 4 (2003), edited by Eric Pawson and Tom Brooking; Landscape/Community, eds. Ballantyne and Bennett; Pawson, and Brooking, 'Introduction', in Environmental Histories, pp. 1-16; Brooking, and Pawson, 'Writing New Zealand's Environmental History', History Now 5, no. 2 (1999): pp. 28-32; Beattie, 'Greener Pastures? Future Research Topics on New Zealand's Environment', ENNZ: Environment and Nature in Nerw Zealand 1, no. 2 (August, 2006): pp. 8-13. The only journal in this area is: ENNZ: Environment and Nature in Nerw Zealand (http://cres10.anu.edu.au/environhist/newzealand/).

80 Some examples of work by scientists and foresters include: Thomas E. Simpson, Kauri to Radiata: Origin and Expansion of the Timber Industry of New Zealand (Auckland, 1973); A.L. Poole, Forestry in New Zealand (Auckland, 1969); Peter McKelvey, Steepland Forests: A Historical Perspective of Protection Forestry in New Zealand (Christchurch, 1995); McKelvey, Sand Forests; A.H. Reed, The Gumdiggers: The Story of Kauri Gum (Wellington, 1972); J.C. Halkett, The World of the Kauri (Auckland, 1986); P.J. Grant, Hawke's Bay Forests of Yesterday: A Description and Interpretation (Havelock North, 1996). Many other examples of forest history exist, especially those on the kauri industry. For a comprehensive list, see Marleene Jean Boyd, Conservation and Management of Nerw Zealand's Indigenous Forests: A Selected Bibliography: 1848-1990 (Auckland, 1993).

81 Roche, Forest Policy in New Zealand; Roche, History of New Zealand Forestry; Roche, Land and Water, Graeme Wynn, 'Pioneers, Politicians and the Conservation of Forests in early New Zealand', Journal of Historical Geography 5, no. 2 (1979): pp., 171-188.

82 Wynn, 'Pioneers, Politicians and the Conservation of Forests in early New Zealand'; Wynn, 'Conservation and Society in late Nineteenth-Century New Zealand', New Zealand Journal of History 11, no. 2 (1977): pp. 124-136; Wynn, 'Destruction under the guise of improvement? The 
Forest History Society has published regular conference proceedings, including most recently a special issue in 2008 of Environment and History. ${ }^{83}$ Suffice it to say, forest history is a relatively rich field of New Zealand's environmental scholarship.

Nevertheless there are a number of new and potentially informative areas of research open to scholars, as demonstrated through the research of the authors of this article, who have both focussed on situating New Zealand's forestry experience in its global context. Recently Paul Star has investigated both the impact of ecological ideas on New Zealand forest policy ${ }^{84}$ and the impact on forests of grasslands expansion..$^{85}$ James Beattie's forthcoming book, Empire and Environmental Anxiety, situates New Zealand colonial forest policy in its wider imperial setting, explored through the idea of 'environmental anxiety' as a stimulus to imperial environmental protection and taking into account conservation in relation to health and aesthetic concerns. ${ }^{86}$

We believe New Zealand forest history can be enriched through the introduction of perspectives and approaches taken from overseas scholarship on

forest, 1840-1920', in Environmental Histories of New Zealand, eds. Pawson and Brooking, pp. 100-16; Star, 'The Place of Native Forest in New Zealand's Mental Landscape'; Star and Lochhead, 'Children of the Burnt Bush', pp. 119-35; Star, 'Native Forest and the Rise of Preservation in New Zealand 1903-1913', pp. 275-94; Lanna Brown, and A.D. McKinnon, Captain Inches Campbell Walker: New Zealand's First Conservator of Forests (Wellington, 1966); Lanna Brown, The Forestry Era of Professor Thomas Kirk, F.L.S., First Chief Conservator of State Forests, New Zealand (Wellington, 1968). For theses, note: Paul Star, 'From Acclimatisation to Preservation: Colonists and the Natural World in Southern New Zealand, 1860-1894'(Ph.D. Thesis, University of Otago, 1997); Ross Alan Galbreath, 'Colonisation, Science, and Conservation: The Development of Colonial Attitudes toward the Native Life of New Zealand with Particular Reference to the Career of the Colonial Scientist Walter Lawry Buller (1838-1906)' (Ph.D. Thesis, University of Waikato, 1989); L.E. Lochhead, 'Preserving the Brownie's Portion: A History of Voluntary Native Conservation in New Zealand, 1888-1935' (Ph.D. Thesis, Lincoln University, 1997); Michael Roche, 'An Historical Geography of Forest Policy and Management in New Zealand, 1840-1930' (Ph.D. Thesis, University of Canterbury, 1983); Geoffrey Alan Wilson, "The Urge to Clear the "Bush": A Study of the Nature, Pace and Causes of Native Forest Clearance on Farms in the Catlins District (SE South Island, New Zealand)' (Ph.D. Thesis, University of Otago, 1991); Beattie, 'Environmental Anxiety in New Zealand, 1850-1920: Settlers, Climate, Conservation, Health, Environment' (Ph.D. Thesis: University of Otago, 2005); Catherine Knight, 'The Paradox of Discourse Concerning Deforestation in New Zealand: A Historical Survey' Environment and History 15 (2009): pp. 323-342.

83 14, no. 4 (November 2008).

84 Star, 'Ecology: A Science of Nation?'

85 Paul Star, 'Native Forests to Empires of Grass: Research on the Construction of New Zealand Grasslands since the 1850s', in Proceedings of the 6th National Conference of the Australian Forest History Society Inc., eds. Michael Calver et al. (Rotterdam, 2005), pp. 575-585.

86 Beattie, Empire and Environmental Anxiety, 1800-1920 (Houndsmills, forthcoming 2010). 
forests. One particularly glaring omission in existing New Zealand scholarship has been a lack of studies on the impact of forest conservation on Māori people. The outcomes of forest policies cut unevenly across New Zealand society, severely affecting Māori, whose access to lands and resources was removed or often severely restricted by forest reservation. ${ }^{87}$ As a correspondent to the Māori-language newspaper Te Wananga noted in 1874, some Māori feared that forestland in Māori hands would be lost to pay for state protection of forests. ${ }^{88}$ To what extent did Māori resist the encroaching state and its reservation of forests? What form did resistance take? In this context, post-colonial perspectives can significantly enrich understandings of Māori experiences and resistance to forest conservation. Though the colonial state never had the hegemonic power ascribed to it by scholars of Subaltern Studies, nevertheless examination of the techniques of resistance might well open up areas of comparison and contrast. ${ }^{89}$ How and why have indigenous resistance in India and New Zealand, for instance, differed or converged, particularly given the remarkable extent of literacy within Māori society? Comparisons drawn from other subjects suggest that New Zealand Māori may have resorted to written and formal means of protest more than those in colonial India, but greater research is required in this area. ${ }^{90}$

Much more also needs to be done on the direct practical contribution of Māori to state forestry, which, ever since the earliest felling of kahikatea spars for British naval ships, has employed a considerable Māori work force. Māori attitudes to the forest were first systematically described in the European world by the somewhat unreliable ethnographer, Elsdon Best, in his work on Maori Forest

87 Brooking, Lands for the People? The Highland Clearances and the Colonisation of New Zealand: A Biography of John McKenzie (Dunedin, 1996), pp. 131-56, 175-82; G. Park, 'Our Terra Nullius', Landfall CCIV (2002): pp. 53-67; Galbreath, 'Displacement, Conservation and Customary Use of Native Plants and Animals in New Zealand', New Zealand Journal of History 36, no. 1 (2002): pp. 36-50. For the later period, see Brad Coombes, 'The Historicity of Institutional Trust and the Alienation of Maori Land for Catchment Control at Mangatu, New Zealand', Environment and History 9, no. 3 (2003): pp. 333-359.

88 Te Wananga 2, no. 5 (12 March 1875): p. 47. See, also, the address of Renata Kawepo and sixteen others against the damage done to streams on Māori land through water dams and logging. 'Petition Relative to the Timber Floating Bill', Journals and Appendix to the Journals of the Legislative Council of Nerw Zealand, No. 8, 1873.

89 On a classic Subaltern Studies text, see Guha, The Unquiet Woods. The hegemony Subaltern scholars have granted to the colonial state is subject to a much-needed criticism: see William Beinart and Lotte Hughes, Environment and Empire (New York, 2007), pp. 269-88.

90 Literacy rates among New Zealand Māori were likely to be considerably higher than those among colonial Indian population. On this, see Tony Ballantyne, 'Archives, Empires and Histories of Colonialism', Archifacts: The Journal of the Archives and Records Association of Nerw Zealand, (2004): pp. 21-36. 
Lore. Frequently the subject of evidence presented before the Waitangi Tribunal in more recent times, the diversity of Māori views deserves more rigorous analysis both for their intrinsic value and for the increasingly strong influence they have had on Pākehā attitudes. ${ }^{91}$

New Zealand forest acclimatisation is another potential area for future research. New Zealand scholarship has invariably zoomed in on the introduction and impact of non-native species into New Zealand, but what about the transfer of New Zealand tree species overseas? Which institutions and individuals were involved and why?92 Similarly, more work is required on the role of private individuals. And, lastly, we think it is time for environmental historians of New Zealand to consider the way they write their history: as a tale of the triumph of nationalism and conservation or as a history of loss, one closely associated with what imperial environmental historian John M. MacKenzie has identified as a strongly declensionist narrative?93

\section{Conclusion}

We argue that for an understanding of New Zealand's forest history from the 1850s to the establishment of permanent state forest conservation, three factors stand out: the cultural baggage of British settlers, the influence of global debates on forestry and related themes, and the characteristics of native New Zealand forest species themselves, all of which were moderated through local experiences of environment, politics and economy. Many British settlers frequently saw bush as an obstacle to settlement, yet some, especially Scots, saw value in protecting a resource which was crucial both to the internal colonial economy and to export earnings. Forestry ideas and personnel flowed freely into and out of New Zealand. Exchanges brought fears about the dangers of climatic deterioration, soil erosion

91 On this, note, for instance, Park, Theatre Country; Elsdon Best, Forest Lore of the Maori: with methods of snaring, trapping, and preserving birds and rats, uses of berries, roots, fern-root, and forest products, with mythological notes on origins, karakia used etc. (Wellington, 1942); Cathy Marr, Robin Hodge, and Ben White, Crown laws, policies, and practices in relation to flora and fauna, 1840-1912 (Wellington, 2001).

92 A useful number of approaches are suggested by the following: Ian Tyrrell, True Gardens of the Gods: Californian-Australian Environmental Reform, 1860-1930 (Los Angeles and London, 1999); Jim Endersby, “From having no Herbarium.” Local Knowledge versus Metropolitan Expertise: Joseph Hooker's Australasian Correspondence with William Colenso and Ronald Gunn', Pacific Science 55, no. 4 (2001): pp. 343-358; Drayton, Nature's Government.

93 'Empire and The Ecological Apocalypse: The Historiography of the Imperial Environment', eds. Tom Griffiths and Libby Robin, Ecology and Empire: Environmental History of Settler Societies (Edinburgh, 1997), pp. 215-28. 
and sand drift, as well as the ideas of timber famine, native displacement and scientific forestry. Other factors, such as religion and aesthetics, tourism and ecology, nationalism and art, contributed to the emergence of scenic and scientific conservation, Arbor Day and national parks from the 1890s. In the early twentieth century, the relative merits of using and not using forests (that is, of conservation and preservation) elicited vigorous debate, particularly over the development of Waipoua Forest. Factors intrinsic to New Zealand included the role of the individual in promoting conservation and the variegated and hilly landscape of the colony. Perhaps of greatest significance were the slower growing rates of native compared to exotic tree species, a factor that greatly encouraged the promotion - and, in due course, the careful scientific selection - of the latter. By examining global contexts of forestry and their interplay with local and internal influences, these aspects of New Zealand's forest history can be better understood and will hopefully invite comparative studies of colonial forest policy elsewhere. 